ACTA UNIVERSITATIS LODZIENSIS

FOLIA LITTERARIA POLONICA 4(34) 2016

http://dx.doi.org/10.18778/1505-9057.34.23

Małgorzata Pawlata*

\title{
Muza w kościele. Poetycka gratulacja Franciszka Dionizego Kniaźnina z okazji konsekracji Księdza Adama Stanisława Naruszewicza Biskupa Koadiutora Smoleńskiego
}

Poetycka działalność Franciszka Dionizego Kniaźnina przypadająca na lata siedemdziesiąte XVIII wieku obfituje w utwory okolicznościowe, uświetniające rozmaite okazje kulturalne i towarzyskie. Młody jeszcze poeta, bywalec dworu księżnej Izabeli Czartoryskiej w Powązkach, komponuje wierszowane bukiety urodzinowe i imieninowe na cześć członków znamienitego rodu, a także ody pochwalne dla przedstawicieli ówczesnego świata kultury i polityki. Utwory te charakteryzują się dużym zaangażowaniem emocjonalnym poety, pozwalają zauważyć serdeczne relacje $\mathrm{z}$ adresatami, a zawarty $\mathrm{w}$ nich panegiryzm nie jest natrętny, gdyż nie wynika z interesownościi. I choć, jak zauważył już Kazimierz Brodziński, Kniaźnin w swej twórczości koncentruje się gównie na „uwielbieniu swobód wiejskich i miłości ojczyzny"2, to w jego obszernej twórczości znaleźć można również utwory dotyczące spraw publicznych ${ }^{3}$.

Adam Naruszewicz w 1775 roku został konsekrowany na biskupa koadiutora diecezji smoleńskiej, uroczystość odbyła się 25 lub 28 maja tegoż roku ${ }^{4}$. Ta okoliczność stała się dla twórców z kręgu „Zabaw Przyjemnych i Pożytecznych” pre-

* Dr, Uniwersytet Łódzki, Wydział Filologiczny, Instytut Filologii Polskiej, Katedra Edytorstwa, ul. Pomorska 171/173, 91-404 Łódź; e-mail: m.pawlata@gmail.com

${ }^{1}$ Por. T. Kostkiewiczowa, Kniaźnin jako poeta liryczny, Zakład Narodowy im. Ossolińskich, Wrocław 1971, s. 102.

${ }^{2}$ K. Brodziński, O Franciszku Dionizym Kniaźninie, cyt. za: Z. J. Nowak, Kazimierz Brodziński (1791-1835), w: Pisarze polskiego oświecenia, t. 3, red. T. Kostkiewiczowa i Z. Goliński, Państwowe Wydawnictwo Naukowe, Warszawa 1996, s. 280.

${ }^{3}$ T. Kostkiewiczowa, Koncepcja poezji i poety we wczesnej twórczości Kniaźnina, w: Prace z poetyki poświęcone VI Międzynarodowemu Kongresowi Slawistów, red. M. R. Mayenowa i J. Sławiński, Zakład Narodowy im. Ossolińskich, Wrocław 1968, s. 212.

${ }^{4}$ Data 25 V 1775 r. podana została w Korespondencji Adama Naruszewicza. 1762-1796. Z papierów po L. Bernackim uzupełnił, opracował i wydał J. Platt, pod red. T. Mikulskiego, Zakład Narodowy im. Ossolińskich, Wrocław 1959 (s. 27, przyp. 1), zaś datę 28 V 1775 r. zawierają dokumenty kościelne przywoływane przez Bolesława Kumora, ta data wydaje się bardziej prawdopodobna, gdyż przypada na niedzielę; zob. B. Kumor, Nieznane przyczynki źródtowe do biografii biskupa Adama Naruszewicza, „Pamiętnik Literacki” 1964 z. 55/2, s. 455-480. 
tekstem do napisania gratulacyjnych ód, poświęconych zaprzyjaźnionemu poecie, który dotychczas wyznaczał standardy oświeceniowemu panegiryzmowi. Łącznie w tomie 12. rocznika 1775 stołecznego periodyku, wydrukowano sześć utworów z tej okazji. Ich autorami byli: Fabian Sakowicz, Józef Komorowski, Urban Szostowicz, Józef Przyłuski, Franciszek Dionizy Kniaźnin i Franciszek Zabłocki ${ }^{5}$.

Utwór Franciszka Dionizego Kniaźnina Oda VI Z tejże okoliczności [konsekracji Ks(iędza) A(dama) S(tanisława) Naruszewicza B(iskupa) K(oadiutora) S(moleńskiego)], zapewne przez wzgląd na okazję, ale także właściwości stylu pisarskiego autora, jest bardzo uroczysty. Poeta opisuje konsekrację niezwykle szczegółowo, zaczynając od wyrażenia podziwu wobec wspaniałego i dostojnego wyglądu nowo mianowanego biskupa. Dalej krok po kroku przedstawia przebieg, odbywającej się w kolegiacie św. Jana w Warszawie, ceremonii, prowadzonej przez brata króla - biskupa płockiego Michała Jerzego Poniatowskiego oraz wymienia osobistości w niej uczestniczące. Kniaźnin w tej części utworu buduje napięcie, jego kulminacyjnym momentem jest oczekiwanie zebranych na błogosławieństwo, którego ma udzielić biskup koadiutor. Wśród oczekujących znalazły się również Muzy przybiegłe z Parnasu, ciekawe toku uroczystości, ale przede wszystkim zadowolone, że w gronie swych poetów mają biskupa. Tym samym Kniaźnin po raz kolejny wykorzystuje charakterystyczne dla swej twórczości połączenie świata rzeczywistego, w tym przypadku przesiąkniętego katolicyzmem, ze światem mitologicznym. Do opisu uroczystości religijnej wprowadza elementy religii politeistycznej, jeszcze niedawno piętnowane jako pogańskie. Zabieg ten pozwala zauważyć, jak dalece tradycje antyczne wchłonięte zostały przez osiemnastowieczną kulturę. Poeta w tym wierszu idzie dalej niż zwykle, bo zaprezentowana przez niego sytuacja liryczna to już nie „cypryjski powiat”, ale Muza w kościele

Sztafaż mitologiczny odpowiada literackim zamiłowaniom Naruszewicza, jednak wobec nowych obowiązków dotychczasowego poety wprowadza pewną dychotomię. Kniaźnin mistrzowsko zestawia postacie sielankowego pasterza i duszpasterza, zastanawiając się, czy kolega po piórze zdoła połączyć obie funkcje:

Coś pierwej trzodę z Fawonim płochem

W leśne zaganiał manowce,

Biskupim teraz musisz posochem

Rozumnie kierować owce.

(w. 69-72)

${ }^{5}$ Wiersz z tej okazji autorstwa F. Zabłockiego omawia B. Mazurkowa, Na ziemskich i niebieskich szlakach. Studia o poezji Franciszka Zabłockiego i Franciszka Dionizego Kniaźnina, Wydawnictwo Uniwersytetu Śląskiego, Katowice 2008, s. 16-17.

${ }^{6} \mathrm{O}$ połączeniach swojskości z obrazowaniem mitologicznym w twórczości Kniaźnina pisał Wacław Borowy, $W$ cypryjskim powiecie, w: tegoż, Studia i rozprawy, t. 1, Zakład Narodowy im. Ossolińskich, Wrocław 1952, s. 77-78. 
Kniaźnin przedstawia całą uroczystość z niekłamanym podziwem, o czym świadczą nagromadzone w tekście wyrazy podnoszące jej rangę, takie jak: „krasa”, „kosztowność”, „powaga”, „honor”, „wesele”. Do opisu uroczystego wydarzenia poeta używa równie uroczystej formy ody, który to gatunek najbardziej odpowiadał perswazyjnemu charakterowi wypowiedzi poetyckiej. Podmiot mówiący w tego typu utworach jest predestynowany do posiadania niepodważalnej wiedzy, którą przekazuje podrzędnemu słuchaczowi, a ten przyjmuje ją za pewnik ${ }^{7}$. Także w tym utworze poeta, będący świadkiem wydarzenia, wymaga od odbiorcy tekstu wiary „na słowo”. Co ciekawe, im bardziej „potomne usta” czytają tekst prezentowanej ody, tym bardziej przybiera ona wartość dokumentalistyczną niż poetycką.

Ostatnia strofa omawianego wiersza jest intersująca nie tyko ze względów poetyckich, ale i dokumentalnych. Poeta ukazuje, że Naruszewicz był dla Stanisława Augusta cenną postacią, ponieważ za pomocą poezji propagował i tłumaczył społeczeństwu często nowatorską, a przez to niezrozumiałą politykę króla ${ }^{8}$. Ponadto Kniaźnin powiadamia czytelnika o praktyce organizowania przez władcę swoistych konkursów poetyckich, które owocowały zazwyczaj kilkoma utworami różnych poetów poświęconymi tej samej okoliczności:

Mając to w myśli, że Muzy darem

Rozniosłeś sławę Augusta

I, że cię August Muzy odmiarem

Podaje w potomne usta.

(w. 113-116)

\section{ANEKS}

Przedstawiony utwór opracowano uwzględniając najważniejsze zasady transkrypcji oświeceniowych tekstów poetyckich, ustalone w kręgu uczestników edytorskich seminariów magisterskich i doktoranckich prowadzonych przez Barbarę Wolską, w Katedrze Edytorstwa Wydziału Filologicznego Uniwersytetu Łódzkiego'.

${ }^{7}$ T. Kostkiewiczowa, Klasycyzm, sentymentalizm, rokoko, Państwowe Wydawnictwo Naukowe, Warszawa 1979, s. 125-126.

${ }^{8} \mathrm{Na}$ szczególne traktowanie Naruszewicza przez króla wskazuje również Jerzy Starnawski w artykule Król Stanisław August jako czytelnik, w: Publiczność literacka i teatralna w dawnej Polsce, pod red. H. Dziechcińskiej, Wydawnictwo Instytutu Badań Literackich PAN, Warszawa- Łódź 1985, s. 180.

${ }^{9}$ Por. A. Naruszewicz, Poezje zebrane, wyd. B. Wolska, t. 1, Instytut Badań Literackich PAN Wydawnictwo - Akademia Humanistyczna, Warszawa 2005, s. 211-217, Biblioteka Pisarzy Polskiego Oświecenia, t. 4; tamże, t. 2, Warszawa 2009, s. 180-186; tamże, t. 3, Warszawa 2012, s. 241-249; 


\section{Oda VI Z tejże okoliczności ${ }^{10}$}

[konsekracji X(iędza)A(dama) S(tanisława) Naruszewicza

$\mathrm{B}$ (iskupa) K(oadiutora) S(moleńskiego)] $]^{11}$

Vester, Camenae, vester ad inclitas

Stat Praesul aras.

Sarbiev[ius, Lyrica IV 2, 21-22] ${ }^{12}$

Gwoli żądaniom wdzięcznego ludu, Stajesz przed ołtarz, Adamie!

Gdzie pod ciężarem świętego trudu

Pasterskie uginasz ramię.

5 Otóż to za kir i czarne szaty,

Coś je był z serca ulubił,

Masz teraz postać jasnej oświaty,

Którą ci honor poślubił.

Infuła blaskiem obwodzi skronie,

10 Krzyż zloty piersi obarcza,

Pastorał wspiera szanowne dłonie,

tamże, t. 4, wyd. B. Wolska, A. Masłowska-Nowak, Instytutu Badań Literackich PAN Wydawnictwo, Warszawa 2015, s. 177-182, Biblioteka Pisarzy Polskiego Oświecenia, t. 11.

${ }^{10}$ Utwór został opublikowany w „Zabawach Przyjemnych i Pożytecznych” 1775 t. 12 cz. 1, s. 25-31, jako ostatnia z sześciu ód adresowanych do Adama Naruszewicza z okazji konsekracji na koadiutora biskupa smoleńskiego; nie znalazł się w późniejszych wydaniach poezji Kniaźnina (zob. E. Aleksandrowska, „Zabawy Przyjemne i Pożyteczne” 1770-1777: monografia bibliograficzna, Zakład Narodowy im. Ossolińskich, Wrocław 1999, s. 12, 74). Publikacja ta stanowi podstawę wydania niniejszej edycji.

${ }^{11}$ Tytuł: Adam Stanistaw Naruszewicz - (1733-1796) poeta, dramatopisarz, historyk, uczestnik obiadów czwartkowych, redaktor „Zabaw Przyjemnych i Pożytecznych”, jezuita, nauczyciel i polityk. Zob. J. Platt, Adam Naruszewicz, w: Polski Słownik Biograficzny, t. 22/1, z. 92, Warszawa 1977, s, 554-556; Koadiutor - biskup pomocniczy, mianowany przez władze zwierzchnie do pomocy biskupowi diecezjalnemu, mający prawo następstwa.

${ }^{12}$ Motto: Wasz ołtarz, Muzy, nawiedza ten oto / Dostojny zwierzchnik. Motto pochodzi z łacińskiej pieśni M. K. Sarbiewskiego Ad Stanislaum Łubieński, episcopum plocensem, Regni Poloniae senatorem, w: tegoż, Liryki IV, 2. w. 21-22. Tłumaczenie za: tenże, Liryki oraz Droga rzymska i fragment Lechiady, przeł. T. Karyłowski TJ, oprac. M. Korolko przy współudziale J. Okonia, Instytut Wydawniczy PAX, Warszawa 1980, s. 302-305.

w. 5 kir - tu: sutanna.

w. 9 infuła - wysokie nakrycie głowy, będące znakiem godności kościelnej np. biskupa, kardynała czy opata; przeważnie wykonane z ozdobnego materiału z ornamentami o tematyce biblijnej.

w. 10 krzyż złoty - pektorał, napierśnik, ozdobny krzyż złoty lub srebrny, zdobiony kamieniami szlachetnymi lub zawierający relikwie, noszony przez dostojników duchownych. W Kościele katolickim symbolizuje wierność Chrystusowi oraz przezwyciężenie cierpienia i śmierci.

w. 11 pastorat - ma przypominać laskę pasterską, jaką posługiwał się Chrystus. Symbolizuje władzę pasterską i prorocką. Wszedł do liturgii w XIII w., może być używany przez biskupa lub opata. 
Fijolet krasy dostarcza.

Kapę ci żankiel zapina drogi,

Palec w kosztownym sygnecie,

15 Złotogłów suty, zdobiąc ci nogi,

Szkarłatny pawiment gniecie.

Zewsząd posługę sprawują księża,

Lud się ubiega ochoczy,

A pragnąc widzieć nadgrodę męża,

20 Radośnie tu zwraca oczy.

Duchowne grono lata z pośpiechem,

Błyszczą poboczne tijary*;

Nowym cię czynią Melchizedekiem,

Jak niesie obyczaj stary.

25 Otoć dwaj męże ubrani świętnie

w. 12 fijolet - fiolet, kolor symbolizujący biskupa, w odróżnieniu od czerwieni symbolizującej kardynała i bieli - znaku papiestwa.

w. 13 kapa - długa ozdobna szata w kolorze fioletowym (w przypadku biskupa), niemająca ścisłego zastosowania liturgicznego, charakteryzuje się długim trenem (cappa magna), który musi być podtrzymywany przez ministrantów.

żankiel - ozdobna klamra okazałych rozmiarów.

w. 14 sygnet - pierścień, symbol władzy (tak świeckiej, jak i duchowej, którą niegdyś posiadali biskupi), nadawany wraz z pastorałem podczas święceń. Pierścień służył jako pieczęć, a także miał symbolizować depozyt wiary zachowywany przez duchownego oraz jego zaślubiny z Kościołem.

w. 15 złotogłów - tkanina z jedwabiu (osnowa) i złotych nici (wątek) wykonanych z płynnego złota; bardzo drogocenna, wykorzystywana do szycia strojów królewskich, a także na szaty liturgiczne: ornaty i kapy oraz buty; wykorzystywany również jako materiał ozdobny.

w. 16 szkartatny - koloru ciemnoczerwonego.

pawiment - ozdobny, intarsjowany lub wykonany z mozaiki parkiet.

w. 22 * Giedroyć, Bisk. Infl; Wodziński Bisk. Smol. [przyp. podst. wyd.];

Jan Stefan Giedroyć herbu Hippocentaurus (1730-1803), w 1. 1763-1765 biskup pomocniczy diecezji białoruskiej, od 1765 biskup diec. inflanckiej i piltyńskiej, od 1778 jako protegowany Ignacego Massalskiego, dzięki poparciu Rosji i króla biskup żmudzki. Na stanowisku tym oskarżany o nepotyzm i chciwość. Przystąpił do konfederacji targowickiej, był przeciwnikiem Konstytucji 3 maja. Odznaczony Orderem Orła Białego i Orderem św. Stanisława.

Gabriel Wodziński herbu jastrzębiec (1727-1788), w 1. 1759-1772 koadiutor diecezji smoleńskiej, od 1772 jej ordynariusz rezydujący w Warszawie. Odznaczony Orderem Orła Białego w r. 1763.

tijara - tiara, potrójna bardzo bogato zdobiona forma mitry w kształcie korony, noszona wyłącznie przez papieży, symbolizująca potrójną władzę: kapłańską, prorocką i królewską. Kniaźnin pisząc o tiarach, opisywał najprawdopodobniej bogato zdobione mitry biskupie (mitra pretiosa), które były dekorowane złotem, szlachetnymi kamieniami lub perłami.

w. 23 Melchizedek - bibl. kapłan Boga Najwyższego występujący w księdze Rodzaju (Rdz. 14, 18-20), w NT porównywany do niego jest Chrystus, jako najwyższy z kapłanów, podobnie jak starotestamentowy wzór jest jednocześnie kapłanem i królem. Ponadto zbieżnością miało być również nieposiadanie przez Melchizedeka rodziców, co wskazywać miało na przekazaniu mu godności przez Boga. 
Złociste trzymają chleby**,

Co z swego daru poświęca chętnie

Dla twej Cerera potrzeby.

Otoć za nimi i drudzy*** kroczą,

30 Słodkim Kościoła zwyczajem,

Co chęć wskazują na cię ochoczą,

Niosąc baryły z tokajem.

Oto i świece, ${ }^{* * * *}$ w okrzyk wesoły

Unoszą dwaj inni w parze,

35 Coć je na Hybli rozkoszne pszczoły

W słodkim ulały nektarze.

Król sam przytomnym pogląda okiem

I swoje oświadcza chęci;

Brat jego*****, idąc poważnym krokiem,

w. 26 ** Piatkowski, Podkom. Krzem; Dziekoński Stoln. Wołkow. [przyp. podst. wyd.];

Właśc. Mikołaj Piaskowski herbu Junosza (1726-1803), podkomorzy krzemieniecki w 1. 1765-1785. Posiadacz ogromnych dóbr ziemskich, początkowo stronnik „,amilii”, posłował na sem konwokacyjny, gdzie współuczestniczył w układaniu paktów konwentów, następnie na sejm elekcyjny. W r. 1766 jako jeden z pierwszych został odznaczony Orderem Św. Stanisława, później wszedł w skład Komisji Skarbowej Koronnej. W r. 1892 przystąpił do konfederacji targowickiej.

Antoni Dziekoński herbu Korab (zm. 1812), od 1765 r. stolnik wołkowyski, członek Rady Nieustającej, od 1768 r. pisarz polny litewski, od 1785 r. podskarbi litewski, poseł na sejm z powiatu słonimskiego. Od 1785 podskarbi nadworny litewski. W 1784 r. odznaczony Orderem św. Stanisława, rok później Orderem Orła Białego. Przeciwnik konstytucji 3 maja, targowiczanin.

w. 26-40 złociste trzymaja chleby... - opis procesji z darami. Najstarszą, a zarazem najskromniejszą formą owej procesji było przyniesienie chleba i wina, później ilość darów rozrosła się, dołączyły do nich płonące świece, ewangeliarz, woda, kwiaty i owoce.

w. 28 Cerera - mit. rz. bogini urodzajów, ziemi uprawnej, zbóż, córka Saturna i Ops; była bóstwem czczonym przez Latynów. Jej atrybutami były kłosy zbóż, kwiaty maku, kogut, cyprys.

w. 29 ***Sosnowski, Wda Smoleń; Czaplic Łowczy W. Koronny. [przyp. podst. wyd.];

Józef Sosnowski herbu Nałęcz (zm. 1783), marszałek sejmu elekcyjnego, wojewoda smoleński od 1771 r., członek Rady Nieustającej, w 1. 1775-1780 hetman polny litewski. W r. 1762 odznaczony Orderem Orła Białego, w r. 1765 Orderem św. Stanisława.

Celestyn Czaplic herbu Kierdeja (1723-1804), od 1773 r. łowczy wielki koronny, poseł sejmów w latach: 1752, 1754, 1758, 1766, 1767 i 1768, a także na sejm koronacyjny w r. 1764. W latach 1778-1780 zasiadał w Radzie Nieustającej. Brał udział w królewskich obiadach czwartkowych.

w. 33 **** Wodziński Podst. Liwsk; Kurzeniecki Sędź. Grodz. Piński. [przyp. podst. wyd.];

Stanisław Wodziński podstoli liwski od 1857 r. generał adiutant hetmana wielkiego litewskiego;

Ignacy Kurzeniecki sędzia grodzki piński w 1. 1772-1780, konsyliarz Rady nieustającej, wielokrotny poseł na sejm. Jako poseł na Sejm Rozbiorowy znajdował się w opozycji.

w. 35 na Hybli rozkoszne pszczoły - góra Hybla (położona na wschodnim krańcu Sycylii) słynęła z bujnej roślinności, a także doskonałych miodów produkowanych przez tamtejsze pszczoły. w. $39 * * * * *$ J. O. X. Biskup Ptocki, Konsekrator [przyp. podst. wyd.];

Ignacy Massalski (1727-1794) od 1762 r. biskup wileński, z jego rąk Naruszewicz przyjął sakrę biskupią. Pisarz wielki lit. w. 1. 1748-1754, w r. 1762 został odznaczony Orderem Orła Białego. 
40 Prowadzi ciebie i święci.

Czekają ludzie, jak rychło święty

Twa ręka krzyż rzuci na nie,

Czeka weselem Kościół przejęty,

Panowie wszyscy i panie.

45 Muzy ciekawe biegną z Parnasu

Co za blask teraz tej głowy,

Co tylko wieniec do tego czasu

Miała na sobie laurowy.

Kontente nazbyt, że mogą dla się

50 Tę mieć w zaciszu zaletę,

Że i biskupa na swym Parnasie,

Nie tylko mają poetę.

Więc każda swojej, co która może,

Okaże podarek chęci:

55 Ta liść z narcysu, ta wdzięczne roże,

Ta z lilii wieniec ukręci.

Że zaś już nowym jesteś pasterzem,

Obłędną zbierając trzodę,

Nowym się tobie zdają przymierzem,

60 Wchodząc pod twoję zagrodę.

A gdy nie własnym podawać głosem

Przyjemną im kontentecę,

To raczysz baczność mieć nad ich losem

I w swojej trzymać opiece.

${ }_{65}$ Tak jest: coś pierwej w teorban złoty,

Prezes Komisji Rozdawniczej Litewskiej, a następnie pierwszy prezes Komisji Edukacji Narodowej. W czasie sejmu czteroletniego okazał się stronnikiem Rosji i płatnym zdrajcą, przystąpił do konfederacji targowickiej.

w. 44 krzyż rzuci - udzieli błogosławieństwa.

w. 45 Muzy ... z Parnasu - Muzy, córki Zeusa i Mnemosyne, bogini pamięci; dziewięć sióstr; łączone z Apollonem - przewodnikiem Muz; każda z nich opiekowała się odrębną dziedziną nauki, sztuki i poezji.

Parnas - pasmo górskie w środkowej Grecji, ze źródłem Kastalia, uchodziło za siedzibę Apollona utożsamianego ze Słońcem.

w. 47-48 wieniec ... laurowy - symbol zwycięstwa, także militarnego, w równej walce, przyznawany dowódcom oraz zwycięzcom igrzysk olimpijskich, których głowy ozdabiano wieńcem splecionym z gałązek laurowych.

w. 58 obłędny - błądzący, pogrążony w błędzie.

w. 62 kontenteca - kontentacja, zadowolenie, radość.

w. 65 teorban - strunowy instrument muzyczny, lutnia basowa; symbol twórczości poetyckiej. 
Lub trącał w Aońską cytrę;

Teraz na wyższe musisz roboty

Starowną obracać mitrę.

Coś pierwej trzodę z Fawonim płochem

70 W leśne zaganiał manowce,

Biskupim teraz musisz posochem

Rozumne kierować owce.

Co pierwej stały otworem wrota

Na Muzy kochanej przyście,

75 Teraz stan rzeczy i postać złota

Zaniedba wawrzynu liście.

Lecz co ja mówię? Ręka się w swoim

Uniosła nieco zapędzie;

Próżno się trwożym i tego boim,

80 Czego tu nigdy nie będzie.

Wiemy, jak w różnej stanu odmianie

Ujmuje statek cię ścisły,

Skąd jednaż zawsze postać i zdanie

Na równym sercu zawisły.

85 Jest to nikczemnych obyczaj ludzi

Zmiennego na wzór księżyca,

Co dzisiaj ciemnym pomrokiem nudzi,

Jutro blask dumny rozświéca.

Albo ów modrzew, co w swym początku

90 Na wiatr się letki ugina;

Niechże wynidzie z cienkiego prątku

I z Austrem wojnę poczyna.

Trwa równo w każdej topola chwili,

Cokolwiek do niej powieje:

w. 66 Aońska cytra - cytra Apollina, instrument muzyczny strunowy, szarpany; posiada od 21 do 92 strun; symbol poezji i atrybut poety.

w. 68 starowny - staranny, troskliwy.

mitra - por. infuła, symbol godności biskupiej.

w. 69 Fawonii - mit. rz. Fawoniusz, utożsamiany z Zefirem, mit. gr. bogiem wiatru zachodniego, syn tytana Astrajosa i zorzy porannej Eos; łagodny wiatr, zwiastun wiosny, opiekun żeglarzy, metaforycznie: znak dobrej pory.

w. 71 posoch - laska biskupia, pastorał.

w. 76 wawrzynu liście - liście laurowe składające się na wieniec; zob. obj. w. 47-48.

w. 92 Auster - południowy gorący wiatr, zapowiadający niepogodę (uciążliwy szczególnie dla żeglarzy na Morzu Adriatyckim); symbol przeszkód życiowych. 
95 Czy Afryk, to się wdzięcznie pochyli,

Czy Zefir, to się roześmieje.

Widzimy z dawna pewne dowody,

Jak równym stąpałeś krokiem;

Acz cię pan mądry przed swe nagrody,

100 Celniejszym upatrzył okiem.

Czy ci Fortuna w głośniejszym sławieniu

Jaśniejszym błyska obliczem,

Czy cię los taił w prywatnym cieniu,

Tyś zawsze Naruszewiczem.

105 Sameć Kameny z młodości zawsze

Na pierwszym staraniu były,

I na tych oko miałeś łaskawsze,

Kto im poświęcał swe siły.

Nie wątpim, że te, zacny biskupie,

110 I teraz twym będą celem,

A choć w rozlicznej twych zabaw kupie,

Zechcesz ich być przyjacielem.

Mając to w myśli, że Muzy darem

Rozniosłeś sławę Augusta

115 I że cię August Muzy odmiarem

Podaje w potomne usta.

w. 95 Afryk - wiatr południowy zapowiadający nagłe pogorszenie się warunków na morzu - silny wiatr i sztorm.

w. 96 Zefir - utożsamiany z mit. rz. Fawoniuszem, zob. obj. w. 69.

w. 101 Fortuna - mit. rz. bogini losu, pomyślności i szczęścia, odpowiednik mit. gr. Tyche; w sztuce przedstawiano ją ze sterem, rogiem obfitości, kołem lub z zawiązanymi oczyma.

w. 105 Kameny - bóstwa italskie utożsamiane z greckimi Muzami, nimfy wodne, wieszczki (od cano - 'śpiewać').

w. 114 Rozniosteś sławę Augusta - aluzja do prokrólewskiej działalności Naruszewicza jako redaktora „Zabaw Przyjemnych i Pożytecznych”, a także twórczości literackiej i historiograficznej propagującej posunięcia Stanisława Augusta Poniatowskiego.

w. 115 odmiar - odwzajemnienie się, odpłata. 


\section{Bibliografia}

\section{Podmiotowa}

Oda VI Z tejże okoliczności [konsekracji X(iędza)A(dama) S(tanisława) Naruszewicza B(iskupa) K(oadiutora) S(moleńskiego)], „Zabawy Przyjemne i Pożyteczne” 1775, t. 12 cz. 1, s. 25-31.

\section{Przedmiotowa}

Aleksandrowska Elżbieta, „Zabawy Przyjemne i Pożyteczne” 1770-1777. Monografia bibliograficzna, wyd. 2 zm. i popr., Wydawnictwo Instytutu Badań Literackich PAN, Warszawa 1999.

Borowy Wacław, $W$ cypryjskim powiecie, w: tegoż, Studia i rozprawy, t. 1, Zakład Narodowy im. Ossolińskich, Wrocław 1952, s. 77-108.

Nowak Zbigniew, Kazimierz Brodziński (1791-1835), w: Pisarze polskiego oświecenia, t. 3, red. T. Kostkiewiczowa, Z. Goliński, Państwowe Wydawnictwo Naukowe, Warszawa 1996, s. $251-283$.

Korespondencja Adama Naruszewicza. 1762-1796. Z papierów po Ludwiku Bernackim uzupełnił, opracował i wydał J. Platt, pod red. T. Mikulskiego, Zakład Narodowy im. Ossolińskich, Wrocław 1959.

Kostkiewiczowa Teresa, Kniaźnin jako poeta liryczny, Zakład Narodowy im. Ossolińskich, Wrocław 1971.

Kostkiewiczowa Teresa, Koncepcja poezji i poety we wczesnej twórczości Kniaźnina, w: Prace z poetyki poświęcone VI Międzynarodowemu Kongresowi Slawistów, red. M. R. Mayenowa, J. Sławiński, Zakład Narodowy im. Ossolińskich, Wrocław 1968, s. 197-219.

Kostkiewiczowa Teresa, Klasycyzm, sentymentalizm, rokoko, Państwowe Wydawnictwo Naukowe, Warszawa 1979.

Kumor Bolesław, Nieznane przyczynki źródłowe do biografii biskupa Adama Naruszewicza, „Pamiętnik Literacki” 1964 z. 55/2, s. 455-480.

Mazurkowa Bożena, Na ziemskich i niebieskich szlakach. Studia o poezji Franciszka Zabłockiego i Franciszka Dionizego Kniaźnina, Wydawnictwo Uniwersytetu Śląskiego, Katowice 2008.

Naruszewicz Adam Stanisław, Poezje zebrane, wyd. B. Wolska, t. 1-4, Instytut Badań Literackich PAN Wydawnictwo - Akademia Humanistyczna, Warszawa 2005-2015, Biblioteka Pisarzy Polskiego Oświecenia.

Platt Julian, Adam Naruszewicz, w: Polski Słownik Biograficzny, t. 22/1, z. 92, Warszawa 1977, s. 554-561.

Sarbiewski Maciej Kazimierz, Liryki oraz Droga rzymska i fragment Lechiady, przeł. Tadeusz Karyłowski, oprac. M. Korolko przy współudziale J. Okonia, Instytut Wydawniczy PAX, Warszawa 1980.

Starnawski Jerzy, Król Stanisław August jako czytelnik, w: Publiczność literacka i teatralna w dawnej Polsce, red. H. Dziechcińska, Wydawnictwo Instytutu Badań Literackich PAN, Warszawa-Łódź 1985, s. 177-185. 


\title{
Małgorzata Pawlata
}

\section{The muse in church. Dionizy Kniaźnin congratulates to the priest Adam Stanisław Naruszewicz, the Archbishop coadjutor of Smoleńsk on his consecration}

\begin{abstract}
(Summary)
The Ode written by Franciszek Dionizy Kniaźnin is the last one in the series of six odes entitled For the occasion of consecration of priest Adam Stanisław Naruszewicz, the Archbishop coadjutor of Smoleńsk (Z okoliczności tejże [konsekracji Ks(iędza) A(dama) S(tanisława) Naruszewicza B(iskupa) K(oadiutora) S(moleńskiego)]. The odes were published in 1775 in the magazine 'Pleasant and useful games' („Zabawy Przyjemne i Pożyteczne”). They are a poetic account of a celebration held on $25^{\text {th }}$ or $28^{\text {th }}$ May 1775 in St. John's collegiate church in Warsaw and at the same time panegyric praising merita of the poet Bishop. The work is very interesting especially as a documentary as it lists names of guests that gathered for the celebrations, one of which was the king Stanisław August Poniatowski. It also shows relationships among the elite of the capital city at the time. It is worth noting that the way of illustrating is typical for Kniaźnin in a sense and introduces mythological elements in the description of religious celebration.
\end{abstract}

Keywords: the Polish Enlightenment; panegyric; occasional poetry; 'Pleasant and useful games' Słowa kluczowe: oświecenie stanisławowskie; panegiryk; poezja okolicznościowa; „Zabawy Przyjemne i Pożyteczne" 